\title{
CREATING THE VALUE CHAIN MILK BETWEEN BOSNIAAND HERZEGOVINA AND CROATIA
}

\author{
Ivana Plazibat ${ }^{1}$, Ferhat Ćejvanović2 ${ }^{2}$,Zorica Vasiljevic ${ }^{3}$
}

\begin{abstract}
Summary
More than ever distribution of fast moving consumer goods (FMCG) between two neighbors, and ex partners in CEFTA 2006, Croatia and B\&H becomes in focus of producers and retailers. Mainly because customs liberation that existed between two ex CEFTA partners ceased to be valid by entering Croatia in EU, and leaving CEFTA. Bosnia and Herzegovina was most important trading partner for Croatia, with the highest rate of trade liberalization within CEFTA 2006. At the same time Croatia was the most important trade partner for B\&H.

According to above mentioned the aim of this paper is to find out the possibility of the promotion of foreign trade between Bosnia and Herzegovina and Croatia for consumer products (milk and dairy products). Those FMCG earlier exchanged between two partners became today more costly. For that reason, to make these products more attractive to their consumers retailers and producers from both countries must jointly work to create greater value, i.e. compensate for the price difference trough creation of the value chain between $B \& H$ and Croatia retailers and producers.
\end{abstract}

Key words: FMCG, value chain, milk, dairy products, Croatia, B\&H

JEL: $Q 17$

\section{Introduction}

The trade plays an important role in the economy and society. However, despite the openness of markets, the effects of the retail trade in the Croatian economy are not satisfactory (Segetlija, 2008). The same observations can be made for the role of trade in the economy of Bosnia and Herzegovina.

1 Ivana Plazibat, Ph.D., Assistant Professor, University of Split, Department for Professional Studies, Split, Livanjska Street no. 5, Republic of Croatia, Phone: +385 21 329 309, E-mail: iplazibat@oss.unist.hr

2 Ferhat Ćejvanović, Ph.D., Associate Professor, Government of Brčko District of B\&Han external associate, Faculty of Economics in Tuzla, Tuzla, Univerzitetska Street no. 8, Phone: +387 35320 820, E-mail: ferhat.cejvanovic@gmail.com

3 Zorica Vasiljević, Ph.D., Full Professor, University of Belgrade, Faculty of Agriculture, Nemanjina Sreet no. 6, Belgrade, Serbia, E-mail: vazor@agrif.bg.ac.rs

EP 2016 (63) 3 (1031-1038) 
The milk production is economically very important because it is in the function of human food production and nutrition of the whole population. From an economic point of view, the milk production is also very important because it is the daily production, which allows the same kind of daily sales on the market, as well as it enhances liquidity, accelerates the capital turnover and creates a sense of security in the economy operations.

The value chain of milk and dairy products includes the full range of activities required to bring a product from production, transportation, processing, and retail up to the final consumer. The value chain of milk and dairy products has been increased by the series of combinations that include the engagement of equipment, labor, knowledge and skills, and raw materials for the production of milk and dairy products.

B\&H and Croatia traditionally had a high degree of trade exchange in agricultural products and in particular in the milk and dairy products' trade. The reasons for the traditionally good trade have roots in the following: the former joint state, territorial cohesion, language, the links between economic entities, as well as in consumers' habits. After the collapse of the former state, the two countries have maintained a high degree of foreign trade.

In the last 15 years $\mathrm{B} \& \mathrm{H}$ and Croatia have signed the agreements on mutual preferential trade in several occasions. It should be particularly noted that in the period from 2007 to mid-2013 it was effective the CEFTA 2006 Agreement whose participants were B\&H and Croatia as well. Croatia was the most important and largest partner in foreign trade for B\&H. Since the

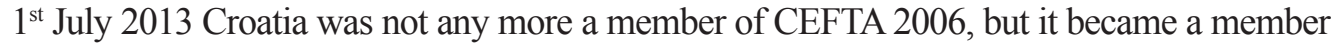
of the European Union.

\section{Material and Method}

In the study there have been used the published scientific and professional articles dealing with the creating value chains' issue, as well as researching data published in the in the publication of the Foreign Trade Chamber of B\&H. They were also used official data of the Statistics Agency of B\&H. The following scientific methods have been used: the desk research method, descriptive method, methods of analysis and synthesis, induction and deduction methods, comparative method as well as the methods of descriptive statistics.

\section{The Value Chain of Milk and Dairy Products in Bosnia and Herzegovina}

The value chain is a series of nine primary and supporting activities which adds value to products or services, i.e. it has been associated the supply side with the demand side of the enterprise business. That is why the creation of profitable value chain requires the harmonization between the wishes of the customers, i.e. of the demand chain and what is created in the supply chain. In order that the supply chains achieve the maximal value, it is necessary to harmonize the supply flow the consumers' value flow, due to rapid changes in their tastes, desires and requirements (Perkov, Ćosić, 2012).

The value chain in the production of milk and dairy products consists of activities and procedures that the product should be available to the consumer. The value chain in the 
production of milk and dairy products begins with production of feed for dairy animals. The dairy animals produce fresh milk by their metabolism and this milk has been transported to the dairy plants, where milk is processed into several dairy products. The produced dairy products have been then packaged and prepared for distribution. The milk and dairy products are distributed to the retail facilities in which they are available to the buyers and consumers. The value chain of milk and dairy products in Bosnia and Herzegovina is shown in the Figure 1.

Figure 1. The value chain of milk and dairy products in Bosnia and Herzegovina

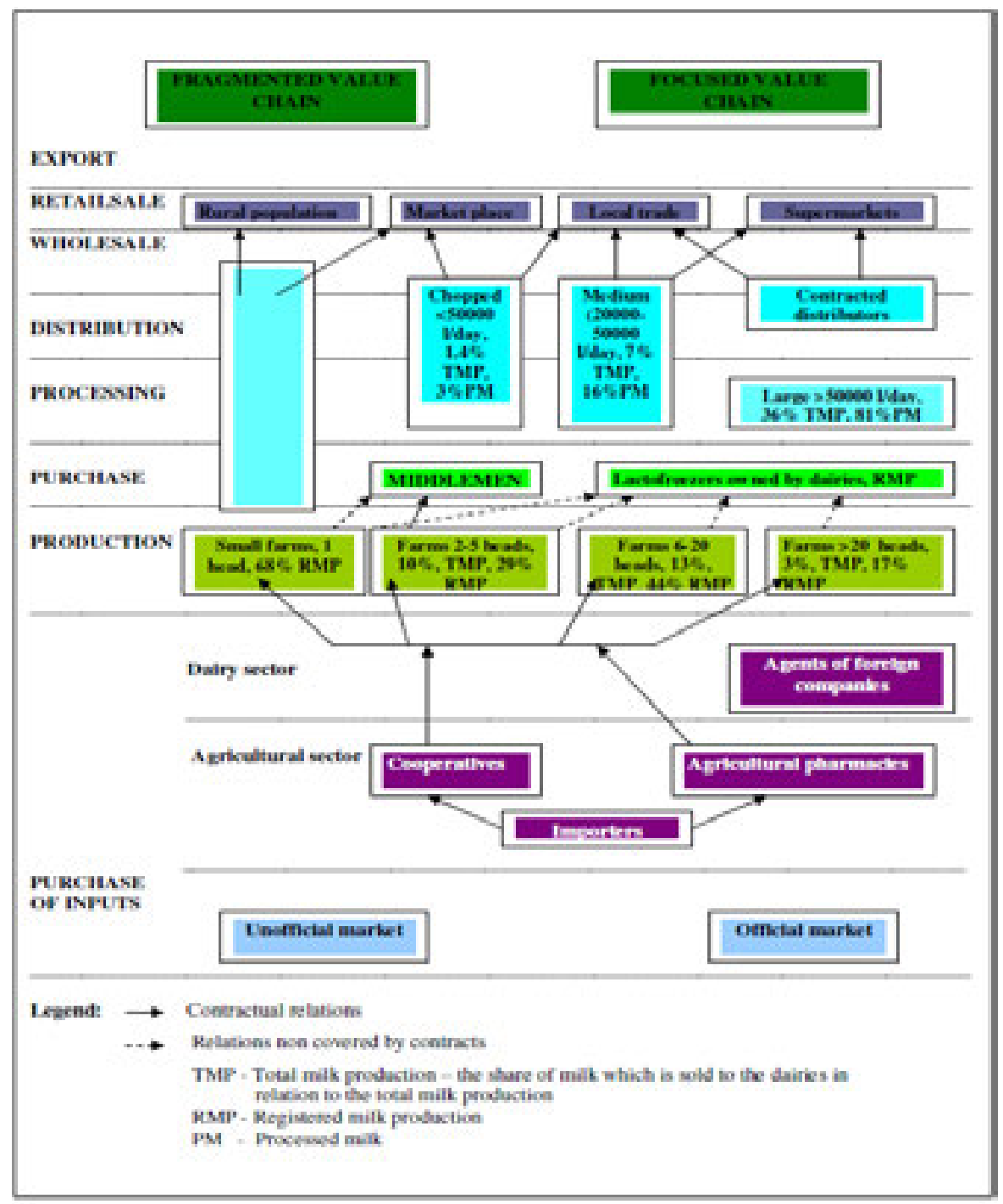

Source: FMPVŠ FBiH - Federalno ministarstvo poljoprivrede, vodoprivrede i šumarstva Federacije Bosne i Hercegovine (2014), Strategija povećanja konkurentnosti i privlačenja ulaganja u vrijednosne lance mlijeka i mliječnih proizvoda i voća i povrća u Federaciji Bosne i Hercegovine, p. 35. 
Each value chain has certain specific characteristics. Such is the case with the value chain of milk and dairy products, which is shown in Figure 1. In this Figure there could not been shown all factors affecting this value chain, e.g. the accompanying institutions, laboratories for the analysis of milk quality, as well as the foreign trade policy of one or more countries.

What is specific for the current situation in the foreign trade of milk and dairy products between B\&H and Croatia are the CEFTA 2006 Agreement and the Agreement on Stabilization and Accession between B\&H and EU. What both countries can do in order to increase the value chain is to develop and improve the quality of milk and dairy products.

\section{Foreign Trade of Milk and Dairy Products between Bosnia and Herzegovina and Republic of Croatia}

The Republic of Croatia became a full member of the European Union on $1^{\text {st }}$ July 2013. Since that day it has been ceased an application of CEFTA 2006 by the Republic of Croatia.

On the other side, until 1st June 2015 Bosnia and Herzegovina had signed the Interim Agreement on Stabilization and Accession with the European Union, and since that date it has been in force the Agreement between the European Union and Bosnia and Herzegovina.

Exiting of Croatia from the membership of the CEFTA 2006 Agreement and joining the European Union has resulted in changes in the foreign trade between $\mathrm{B} \& \mathrm{H}$ and Croatia. The reason for this is before all in different foreign trade conditions between the members of the CEFTA 2006 Agreement and the European Union. Namely, in the framework of CEFTA 2006 Agreement, between the member states there was no restrictions in trade, there was no customs duties and no quotas for certain agricultural products.

Table 1 shows the foreign trade of milk and dairy products between B\&H and Croatia in the period 2011-2014.

Table 1. The foreign trade of milk and dairy products between B\&H and Croatia in the 20112014 period

\begin{tabular}{|c|c|c|c|c|c|c|}
\hline \multirow{3}{*}{ Year } & \multirow{3}{*}{$\begin{array}{l}\text { Export from } \\
\text { B\&H to } \\
\text { Croatia } \\
(€)\end{array}$} & \multirow{3}{*}{$\begin{array}{l}\text { Import from } \\
\text { Croatia } \\
\text { to } \mathrm{B} \& \mathrm{H}(€)\end{array}$} & \multirow{3}{*}{$\begin{array}{l}\text { B\&H/ } \\
\text { Balance } \\
\quad(€)\end{array}$} & \multirow{3}{*}{$\begin{array}{c}\mathrm{Hr} / \\
\text { Balance } \\
(€)\end{array}$} & \multirow{2}{*}{\multicolumn{2}{|c|}{$\begin{array}{c}\text { Trend } \downarrow \uparrow \\
\text { B\&H and Croatia } \\
\%\end{array}$}} \\
\hline & & & & & & \\
\hline & & & & & $\begin{array}{c}\text { Export } \\
\text { from } B \& H\end{array}$ & Import to $\mathrm{B} \& \mathrm{H}$ \\
\hline 2011 & $23,638,542$ & $38,116,737$ & $-14,478,195$ & $14,478,195$ & - & - \\
\hline 2012 & $23,336,695$ & $25,138,298$ & $-1,801,603$ & $1,801,603$ & -1.27 & -34.04 \\
\hline 2013 & $13,994,172$ & $23,247,228$ & $-9,253,056$ & $9,253,056$ & -40.03 & -7.52 \\
\hline 2014 & - & $17,059,579$ & $-17,059,579$ & $17,059,579$ & -100.00 & -26.61 \\
\hline
\end{tabular}

Source: Calculated by the authors based on data collected from the Foreign Trade Chamber of B\&H, available at http://komorabih.ba/vanjskotrgovinska-razmjena/ 
The analysis of data presented in Table 1 shows that the trade of milk and dairy products between B\&H and Croatia had fluctuations in the analyzed period (2011-2014). Export of milk and dairy products from B\&H to Croatia in 2011 and 2012 was almost at the same level (over 23 million $€$ ). Export in 2013 fell to the level of about 14 million $€$, representing a decrease of $40 \%$. In 2014 there was no export of these products from B\&H to Croatia. The reason for that was in the fact that Croatia became the EU member state since $1^{\text {st }}$ July 2013 and the milk and milk products produced in B\&H did not meet the standards of the EU market any more. Import of milk and dairy products from Croatia to B\&H had continuous drop in the analyzed period and it amounted around 38 million $€$ in 2011, while in 2014 it dropped to the level of 17 million $€$. The largest fall in import of milk and dairy products was recorded in 2014.

Namely, accession of Croatia to EU have changed the conditions for import of the Croatian products into $\mathrm{B} \& \mathrm{H}$, because the Croatian products got the same regime as other EU products which are imported to B\&H. The Agreement on Stabilization and Accession (SAA) between EU and B\&H determined that milk and dairy products have a customs duty rate of $10 \%$ as well as the additional levies. These protective measures significantly increase the selling prices, thus making the milk and dairy products less competitive in the market of Bosnia and Herzegovina. The foreign trade deficit of B\&H in trade with Croatia amounted to about 14.5 million $€$ in 2011. In 2012, the deficit was reduced considerably and it amounted to approximately 1.8 million $€$. In 2013 the foreign trade deficit again had the increasing trend and amounted to over 9 million $€$, while in 2014 the deficit was as much as it was the whole import value of the products imported from Croatia to B\&H (over 17 mil. $€$ ).

By accession of Croatia into the EU, there have been officially ceased to be applied certain customs benefits in the framework of CEFTA 2006 Agreement, which Croatia had in the foreign trade with Bosnia and Herzegovina, as since $1^{\text {st }}$ July 2013 the foreign trade exchange between the two countries takes place under the regulations of the Agreement on Stabilization and Accession (SAA).

It should be noted that the current food safety system in Bosnia and Herzegovina has not met all the criteria which ensure obtaining the export licenses for the EU market, so since 1st July 2013 it was stopped the export of milk and dairy products on the Croatian market.

What B\&H and Croatia should do in the future is to find a new market chain for the milk and dairy products in order to make them present on the markets of both countries. The institutions in $\mathrm{B} \& \mathrm{H}$ are currently working on the preparation and harmonization of domestic legislation with European regulations in order to fully meet all the conditions which will enable the export of the animal origin products to the EU, so the milk and dairy products as well.

\section{Discussion on the Improvement of the Milk and Dairy Products' Trade between Bosnia and Herzegovina and Croatia}

An implementation of the SAA obligations, especially those that create the conditions and allow export of milk and dairy products, is a task of institutions in Bosnia and Herzegovina 
in the coming period. Also, B\&H should identify the alternative markets (e.g. Turkey and Russia) for sales of milk and dairy products.

Bosnia and Herzegovina is facing with the condition that must be met in order that milk and dairy products could be exported on the EU market, which is primarily related to the acceptance of European standards which B\&H producers must achieve and accept, and what needs to be approved and agreed by the EU.

After accession of Croatia to European Union, there has been a change in respect of imports from objects of Croatian origin. The objects of Croatian origin were able to continue to export to Bosnia and Herzegovina if they got approvement by the Croatian authority competent for trade with other EU member states and if they are listed on the EU lists of approved facilities.

All objects of Croatian origin which did not meet the cited requirements in accordance with the laws in force in Bosnia and Herzegovina were not be able to make imports into B\&H since $22^{\text {nd }}$ July 2013 and they have been deleted from the Register of Veterinary Office of Bosnia and Herzegovina.

A great problem in the food safety and standards in the value chain of milk and dairy products are insufficient laboratory capacities in $\mathrm{B} \& \mathrm{H}$, as well as the systems for analysis of the fresh milk quality. This is also a chance and an opportunity to be increased the value chain of milk and dairy products in this segment. And this increase is reflected in need for modernization and procurement of the high standard equipment for analysis of a larger number of samples in accordance with the EU standards. The meeting of the EU standards creates the conditions for higher exports of milk and dairy products and increase of production value.

Since September 2015 the European Union has allowed the export of dairy products from Bosnia and Herzegovina to the European Union countries. Four dairy plants in Bosnia and Herzegovina have obtained permission to export to the EU countries, and those are the following dairy plants: Livno, Mlijekoprodukt from Kozarska Dubica, Milkos Sarajevo and Megle Bihac. It is expected in the future that foreign trade of dairy products between Bosnia and Herzegovina and Croatia will reach the level as before the accession of Croatia to EU.

\section{Conclusion}

The competition fast moves the business environment, irreversibly changing the supply chain and management of its functions. Traditional supply chain is connected linearly. Modern approach in the supply chain management assumes that the organizations have to improve communication and flow of information. In this way, the traditional supply chain has been transformed into the adaptive and real-time supply network. This allows the organizations to achieve the management by the flexible, fast-responding network of supply chain as a single entity. The supply chain networks represent very complex, interdependent structures, with a large number of related suppliers, service providers and buyers who are also the members of other supply chains (Rejman-Petrović et al., 2012).

One of the essential prerequisites that every economic subject has to fulfill when placed in an organized market economy is the ability to respond faster to the changes and demands from 
that environment. In this sense, it is necessary to create quite certain assumptions in order to be timely respond and adapt to the conditions imposed by the environment and at the same time, by adequate development policy to impose to the market the own production programs (Bošković, 2013).

By development of the trade business entities and their cooperative formations it should be started development of production companies in the area of food products and thus it should be enabled the improvement of the foreign trade balance in this sector. The new and more efficient organizational forms of distributive trade (particularly the new types of stores) should be established based on the use of modern management technologies and business strategies that take into account the complete value chains (Ćejvanović et al., 2015).

To the economic subjects within distributive trade of food products there have been offered possibilities of modern solutions in their development strategy. This would result in their higher efficiency and thus competitiveness in the domestic and foreign markets. The international value chains, particularly for the small countries such as Republic of Croatia, offer prospects for economic development (Segetlija, 2008).

What should be emphasized it is the importance of knowledge and skills for improvement of the added value along the value chain of milk and dairy products. First of all it is necessary to fulfill the (new) customers' requirements, together with more effective communication with partners in the value chain. Furthermore, it is necessary to benefit from the exchange of information and cooperation with partners along the value chain, together with participation in innovative processes. It is particularly important to recognize where could be made the profit in the value chain of milk and dairy products.

In the analysis of the milk and dairy products' value chain in $\mathrm{B} \& \mathrm{H}$ and Croatia it came to the conclusion that the accession of Croatia to the European Union on the $1^{\text {st }}$ July 2013 changed circumstances in terms of import from Croatia to B\&H. The objects of Croatian origin were able to continue to be exported to Bosnia and Herzegovina if they have been approved by the competent Croatian authority for trade with other EU member states and if they are listed on the lists of approved objects in EU. Based on the all abovementioned, it can be concluded that although B\&H and Croatia have traditionally well-developed trade in the area of milk and dairy products, by accession of Croatia to the European Union, those trade relations have been deranged. In this regard, it is necessary that both countries find the ways for solutions emerged in new situation, i.e. to find the value chain in the trade of milk and dairy products in order to increase the value and advance the foreign trade exchange of milk and dairy products for the benefit of both countries.

In general it can be concluded that the expansion of the EU market by accession of a new member (Croatia) caused the significant changes in economic flows between Bosnia and Herzegovina and its most important trade partner - Republic of Croatia. 


\section{Literature}

1. Bezić, H. (2011): The distribution of agricultural products: fruit and vegetables market in Osijek, Zborornik radova "Poslovna logistika u suvremenom menadžmentu-Business logistics in modern management", Sveučilište Josipa Jurja Strossmayera u Osijeku Ekonomski fakultet u Osijeku, pp. 108.

2. Bošković, J. (2013): Upravljanje lancima snabdevanja: (FQ 2013, festival kvaliteta), 40. Nacionalna konferencija o kvalitetu i 8. Nacionalna konferencija o kvalitetu života, Univerzitet u Kragujevcu, Fakultet inženjerskih nauka, pp. 116-127.

3. Bardak, U. (2012): ETF analiza lanca vrijednosti u sektoru mljekarstva: ciljevi, logika $i$ očekivani rezultati, European Training Foundation (ETF), Podgorica, pp. 1-10.

4. Ćejvanović F., Plazibat I., Vasiljević Z., (2015): Improvement of management in the supply chain of fruits and vegetables in Bosnia and Herzegovina, trade perspectives 2015 Innovations in food retailing, Proceedings of The International Scientific Conference, Edited by : Nikola Knego, Sanda Renko, Blaženka Knežević, University of Zagreb Faculty of Economics and Business Croatian Chamber of Economy, Zagreb, Croatia, 18th and 19th November 2015, pp. 78-92.

5. Perkov, D., Ćosić, D. (2012): Usporedba lanca vrijednosti i lanca opskrbe, Zbornik Visoke poslovne škole „Libertas“, (Ed. Ivo Andrijanić), Zagreb, 15. Novembar 2012, pp. 137-150.

6. Plazibat I., Brajević, S. (2009): Supply chain management in retail industry, Zbornik radova "Poslovna logistika u suvremenom menadžmentu", Ekonomski fakultet u Osijeku, pp. 133.

7. Rejman-Petrović, D., Milanović, I., Kalinić, Z. (2012): Arhitekture lanaca snabdevanja u e-okruženju, Ekonomski horizonti, Vol. 14, Ekonomski fakultet Univerziteta u Kragujevcu, pp. 37-50.

8. Segetlija, Z. (2008): Trgovina u vrijednosnom lancu prehrambenih proizvoda; Zbornik radova sa VIII Međunarodnog znanstvenog skupa "Poslovna logistika u suvremenom menadžmentu" (Ed. Segetlija Zdenko and Karić Marijan), Ekonomski fakultet u Osijeku, Osijek, pp. 241-262.

9. FMPVŠ FBiH - Federalno ministarstvo poljoprivrede, vodoprivrede i šumarstva Federacije Bosne i Hercegovine (2014): Strategija povećanja konkurentnosti i privlačenja ulaganja u vrijednosne lance mlijeka i mliječnih proizvoda i voća i povrća u Federaciji Bosne i Hercegovine, Sarajevo, pp. 29-37. 